\title{
Dress at Choral Evensongs in the Dutch Context - Appropriation and Transformation of Religiosity in the Netherlands
}

\author{
HANNA RIJKEN \\ Protestant Theological University, Amsterdam \\ MARTIN J.M. HOONDERT \\ Tilburg University \\ MARCEL BARNARD \\ Protestant Theological University, Amsterdam \\ Vrije Universiteit Amsterdam
}

\begin{abstract}
This article studies the appropriation of Anglican choral evensong, and more specifically, dress at choral evensong, in the Netherlands outside the context of the Anglican Church to gain more insight into religiosity in the Netherlands. The authors explore the dress worn at choral evensong in the Netherlands and the meanings participants attribute to it. The concepts of denotational and connotational meanings are used as an analytical tool.

In analysing their interviews, the authors came across three categories of meaning and function participants attribute to dress at choral evensong. The first category was the reference to 'England as a model'. By wearing Anglican dress, choirs indicate they belong to the highquality sound group of English cathedral choirs. At the same time, by changing the Anglican 'dress code', choirs emphasise their unicity and individuality, independent of church traditions. The second category was the marking of identity: choirs copy the dress from the English tradition, but add some elements to mark their own identity. Besides this marking of identity, aspects of unicity, uniformity, group identity, and gender-marking also play a part. The third category was metamorphosis and transcendence. Choir members refer to unarticulated transcendental experiences by wearing ritual liturgical dress. On the one hand the authors noted a 'cathedralisation' or 'ceremonialisation' of the singers' dress, and on the other a de-institutionalisation, for example, in the dress of the minister, if present. The article's main conclusion is that the fieldwork data reveal that dress at choral evensong in the Netherlands points to changing religiosity at two different levels. First, the authors observe a transformation in the way religion is expressed or ritualised in Reformed Protestant churches in the Netherlands. The popularity of evensong suggests a longing for
\end{abstract}


other forms of worship, with a focus on ceremonies and Anglican-like vesture for the singers. Second, they observe a mix of concert practices and Anglican-like rituals, which the interviewees in our research refer to as a new form of religiosity. In both practices the traditional dress of the Anglican Church is used, whether copied exactly or adapted. A new phenomenon may be observed: choirs wear Anglican-like vesture decoupled from the Anglican Church as they are longing for transcendental experiences which they find in the musical-ritual form and high musical quality of choral evensong.

Keywords: choral evensong, dress, music, identity, religiosity, transformation, transcendence

Since the 1980s a growing number of choral evensongs have been organised in the Netherlands outside the context of the Anglican Church. They attract many people. The choral evensongs are organised either as (mostly reformed) worship or as a concert, or as both worship and a concert. Choirs dress in traditional Anglican choral vesture and sing a complete Anglican choral evensong. Sometimes choirs change the dress code of the Anglican tradition. This semi-ecclesiastical performance in a secularised country like the Netherlands commands attention and raises questions. What does this ecclesial-like 'show' of choral evensongs signify?

In this article we investigate the dress at these choral evensongs from the perspective of ritual and liturgical studies. The article is part of the $\mathrm{PhD}$ research project 'My Soul Doth Magnify': The Appropriation of the Anglican Choral Evensong in the Dutch Context', which is embedded in the Research Programme 'Practices of Faith in Socio-Cultural Networks' at the Protestant Theological University in Amsterdam. ${ }^{1}$ The research project will explore four liturgical-ritual perspectives of choral evensong: space, language, music, and dress. This article's focus is on the dress worn at these choral evensongs. ${ }^{2}$

The context of our research is the Netherlands. In the first paragraph of this article we called the Netherlands a secularised country. This is insufficiently precise. In line with the severe critique of the secularisation thesis we observe not a decline in religion, but a shift. As early as 2006 the Academic Council for Government Policy published the report Geloven in het publieke domein

1 The first author of the article is the project's main investigator. She gathered and analysed the data. The analysis of data was inter-subjectively assessed by the co-authors, who are also the supervisors of the research project.

2 Part of this introduction is based on the article 'My Soul Doth Magnify': The Appropriation of the Anglican Choral Evensong in the Dutch Context - Presentation of a Reserach Project.'Yearbook for Liturgical and Ritual Studies 29 (2013), 83-98. 
('Believing in the Public Domain'). This report shows the influence of churches is diminishing, but religion is not disappearing. It is being transformed and transferred, and it emerges in unexpected forms and in unexpected places (Van de Donk 2006). This is confirmed in more recent publications about religiosity in the Netherlands, as expressed in all kinds of ritual forms (e.g. Barnard, Cilliers \& Wepener 2014; De Hart 2011/2013; Jespers 2009). The processes of transformation are reflected in ritual practices and these coincide with a reinvention and appropriation of ritual-liturgical repertoires (Rijken, Hoondert, Barnard 2013, 95). The recent publication God in Nederland 19662015 (Bernts \& Berghuijs 2016, 25-7) shows that while there is an ongoing decline in churchgoing, there is also a new spirituality outside and inside the churches, with a hankering for transcendence (Bernts \& Berghuijs 2016, 172). There are no strict borders between the different shapes that religion assumes: people inside and outside the churches, looking for depth and connection, combine elements from different traditions (Bernts \& Berghuijs 2016, 139). The popularity of choral evensong in the Netherlands may be a sign of this hankering for transcendence. By researching part of the material culture of this musical-ritual form, we aim to address this issue. In this article, therefore, we research the appropriation of dress at choral evensong to gain more insight into religiosity in the Netherlands. In general, dress 'provides a window through which we might look into a culture, because it visually attests to the salient ideas, concepts and categories fundamental to that culture' (Arthur $1999,1)$. Sociologist Tim Dant explains that society cannot be understood independently of the material culture, including fashion and dress, used within it (Dant 1999, 107). This leads to the article's main question: how is Anglican choral evensong, and more specifically its associated dress, appropriated in the Netherlands outside the context of the Anglican Church? We divide this main question into two sub-questions: (1) what kind of dress do singers wear at choral evensong in the Netherlands? (2) which meanings and functions do participants attribute to dress at choral evensong? The article aims to contribute to the research into the changing position of religion in the Netherlands.

The article is constructed as follows. First, we give some background information about the tradition of choral evensong in England, and explain which liturgical vesture is worn at choral evensong in the United Kingdom and how choral evensong has been adopted and organised since 1980 in the Netherlands. Second, we present our theoretical framework, which uses the following key concepts: appropriation, transformation of religiosity, materiality, and the meaning of dress. Third, we elaborate on the method used. Fourth, we present our field work, exploring dress at choral evensong in 
the Netherlands. Finally, we reflect on our fieldwork and relate the results to our theoretical framework.

\section{Choral evensong in the UK and in the Netherlands}

\section{Choral evensong in the UK}

Choral evensong is a daily prayer service in the Anglican Church celebrated in the late afternoon or evening. According to John Gibaut Anglicans have 'a rich heritage of daily liturgical prayer' (Gibaut 2006, 451). Choral evensong was established in the sixteenth century, during the English Reformation, but its roots lie in the Early Church: early Christianity took over the practice of daily prayer from Judaism (Gibaut 2006, 451). During the English Reformation Archbishop Thomas Cranmer introduced vernacular liturgy to England. When the monasteries were closed, the daily office became part of congregational worship. The services were intended as daily public worship for everyone. Cranmer reduced the liturgy of the hours to matins (morning prayer) and evensong (evening prayer). Vespers and compline were merged into a single liturgy (Gibaut 2006, 453-454). In 1549 the first Book of Common Prayer was published, including an order for evensong. After some revisions the Book of Common Prayer reached its final form in 1662. This 1662 order is still celebrated daily at choral evensongs in Anglican cathedrals and colleges. Singing daily choral evensong is one of the main tasks of every English choir connected to a cathedral or college.

The usual Anglican chorister's dress at choral evensong consists of a cassock, 'the basic garment worn by ministers (often black) and choir members (often coloured)' (Ruffer 2009, 131), and a surplice, 'a loose white garment with wide sleeves worn over the cassock by some choirs and lay and ordained ministers at certain services' (Ruffer 2009, 131). In England, during the Oxford Movement ${ }^{3}$ in the nineteenth century, the choristers moved from the choir loft to the front of the church building, and began to wear the dress of the clergy. Until today it is a characteristic of vesture at English choral evensongs that the singers wear the same dress as the clergy: a cassock with a surplice, although there are small differences: for example, English boy choristers wear badges and ribbons. During concerts choirs wear cassocks without surplices or formal dress.

\footnotetext{
3 'A renewal movement centred at the University of Oxford which sought a renewal of 'catholic' ... thought and practice within the Church of England (....).', source: Online Encyclopaedia Brittanica <https://www.britannica.com/event/Oxford-movement>, accessed November 17, 2015.
} 


\section{Choral Evensong in the Netherlands}

In 1983 the Schola Davidica Utrecht was one of the first choirs to introduce choral evensong to the Netherlands. Organist Gert Oost was one of the initiators. Jan Valkestijn, Director of Music at Haarlem Cathedral, and Bouwe Dijkstra, founder and first conductor of the Roden Boys Choir, were two other pioneers in the country. The last thirty years have seen a growing number of Anglican-style choral evensongs in the Netherlands. Boys' choirs and evensong choirs have been established, among them the Roden Boys Choir (1985) and the Kampen Boys Choir (2002).

We have observed three different contexts in which choral evensongs in the Netherlands are organised (Rijken, Hoondert, Barnard, 2013, 85). First, an evensong is sometimes organised as worship linked to-mostly-Reformed congregations (both strictly Reformed and ecumenically oriented Reformed congregations), and sometimes in Roman Catholic or Old Catholic parishes. In Reformed worship the order of evensong is adapted to the Reformed liturgy (there is no altar, no kneeling, no cross and candles, no standing during the doxologies, etc.) and the role of the choir is - compared with Anglican evensongs - sometimes more concert-like: a choir performance added to Reformed worship. Second, in other situations evensongs are organised as concerts (with entrance tickets, a programme, and applause) but performed liturgically according to the Book of Common Prayer (1662), with prayers, psalms, lessons, canticles, anthems, and hymns. The choirs rent a church building to perform an evensong (without clergy) as an independent concert-like, but ritualised event. Third, according to the self-understanding of the choirs an evensong is occasionally offered as both concert and worship. It is important to understand that the contexts in which evensongs are organised tell us nothing about the individual appropriation of evensong.

\section{Concepts and theoretical framework}

\section{Appropriation and transformation of religiosity}

One of the key concepts in this article is 'appropriation', which we derive from the Dutch cultural historian Willem Frijhoff. He defines it as follows: 'Appropriation is the process of interpretation with which groups or individuals provide a new meaning for external bearers of meaning, so that the latter become acceptable, liveable, bearable, or even dignified' (Frijhoff 1997, 108). Frijhoff used 'appropriation' in the context of his historical research, 
but in our opinion it is quite applicable to the situation of contemporary liturgical rituals. Frijhoff promotes a change in the focus of research, from top-down to bottom-up. Liturgical research long used to examine the topic through the eyes of the churches and science. Our research also attempts to get an idea of the liturgical ritual practice itself and its reception and perception by participants. The focus of research referred to here can be traced, via Chartier (Chartier 1988), to the Jesuit De Certeau (De Certeau 1984). It has shifted from prescribed ritual to living, liturgical ritual practice. This means that choral evensong is not only seen as a prescribed liturgical order and subject of the scientific research of ecclesiastical guidelines and rubrics, but also as a bearer of meaning in a process of finding meaning and significance. We focus on the material appropriation of dress (which dress participants wear) as well as on the attribution of meaning (why they wear it and what it means).

Another key concept in this article is 'transformation of religiosity'. We recognise this concept in international studies, for example, Wolfe's The Transformation of American Religion: How We Actually Live Our Faith (Wolfe 2003) and Norris and Inglehart's Sacred and Secular: Religion and Politics Worldwide (Norris and Inglehart 2004). We use the term in this article as it is described in the previously mentioned report Geloven in het publieke domein by the Academic Council for Government Policy (Van den Donk et al 2006). Religion is making a surprising comeback. Some people speak of post- or de-secularisation, but it may be better to speak of the transformation of religion (Van de Donk \& Jonkers 2006, 14). Religion is back, but in new and sometimes radical forms other than those of institutional religion. Sengers speaks of the 'transformation of religiosity' (Sengers 2005), and Borgman speaks of a 'metamorphosis' (Borgman 2006). In Heiligen, idolen, iconen Frijhoff mentions a 'transfer of sacredness': '...namely the widening of the use of religious and sacral categories to the domain outside the church [...]' (Frijhoff 1998, 37). This transformation requires a re-evaluation of academic concepts. Concerning religiosity in transformation, we use Pete Ward's concept of 'a liquid church' (Ward 2002). This implies a religiosity which is migrating from the walls of the church to outer domains, and which is therefore also a religiosity in transformation (as described by Barnard, Cilliers and Wepener 2014). However, in our research the interesting phenomenon is that choral evensong is not literally moving away from the walls of the church. The musical ritual is performed within the walls of the church building, but often not in the context of worship connected to a church community. Concerning 'religiosity', an open and situational 
description has been chosen. In the typology of the sacred elaborated by Matthew Evans (Evans 2003) a broad spectrum of religion and religiosity is discussed (from religion bound to tradition and the institution - the religious sacred - to spirituality connected to individual appropriation - the spiritual sacred). However, our article concerns itself with the interesting fact that it is precisely the traditional form of choral evensong (religion bound to tradition and institution) which is appropriated as a form of new religiosity.

\section{Religiosity and materiality}

An important question emerges from studying the research field: is dress at choral evensong linked to religiosity, and if so, how? Birgit Meyer, a leading author on this issue, pleads for a material approach to religion as opposed to a mentalistic understanding of it (mainly grounded in the Protestant Calvinist tradition; Meyer speaks about 'bias'), which takes 'as its starting point the understanding that religion becomes concrete and palpable through people, their practices and use of things [...]' (Meyer 2012, 7). This is an important notion because in the (mainly) Protestant understanding of religion there is a devaluation of practices, materials, and forms as merely 'outward' (Meyer 2012 , 8). Meyer pleads for an integrating approach in which the mental dimension is included within a material approach (Meyer 2012, 12). She advocates the rehabilitation of 'form' in the study of religion and observes that religions offer 'authorized forms for having certain religious experiences (...)' (Meyer 2012, 11). Later, she emphasises the importance of form as a generator of meaning and experience:

We need to acknowledge the indispensability of form, understood not as a vehicle but as a generator of meaning and experience, in all religious practice, irrespective of whether this is fully acknowledged or neglected from within (Meyer 2012, 11-12).

To arrive at a better understanding of how religious mediation works, Meyer has developed the concept of 'sensational form' (Meyer 2012, 26). This term, which she uses as a methodological tool, refers to a 'configuration of religious media, acts, imaginations and bodily sensations in the context of a religious tradition or group' (Meyer 2012, 26). Sensational forms are authenticated as 'harbingers of what lies "beyond"' and have a double character: 'streamlining or shaping religious mediation' and 'achieving certain effects by being performed' (Meyer 2012, 26). She points to the liturgy of a church service as 
an example of a sensational form: 'it stipulates the appropriate steps and, in the course of being performed, induces in participants an experience of divine presence' (Meyer 2012, 26). She underlines the need for a broad definition of religion which allows for this material approach. We follow Meyer in her definition of religion: 'particular, authorized and transmitted sets of practices and ideas aimed at "going beyond the ordinary", "surpassing" or "transcending" a limit, or gesturing towards [...]' (Meyer 2012, 23).

\section{The meaning of dress: representation and communication}

A third element in our theoretical framework is the meaning of dress, and the relationship between dress, identity, religiosity, and music.

The concept of 'appropriation' is closely related to the concept of 'representation' (Hall 1997). In his book Representations Stewart Hall mentions that meaning is produced 'whenever we express ourselves in, make use of, consume or appropriate cultural "things"; that is, when we incorporate them [...] and in this way give them value or significance' (Hall 1997, 3 and 4). He explains that representation is 'an essential part of the process by which meaning is produced and exchanged' (Hall 1997, 15). He uses representation with 'signifying practices': these practices 'use some element to stand for or represent what we want to say, to express or communicate a thought, concept, idea or feeling' (Hall 1997, 4). For example, representation involves the use of dress, which stand for or represent things (Hall 1997, 15).

According to a definition on dress provided by Eicher and Roach-Higgins (Eicher \& Roach Higgins 1992/1993, 15) dress is 'an assemblage of body modifications and/or supplements displayed by a person in communicating with other human beings'. We expect this definition to be useful in our context, although in worship there may be an intention to communicate with the divine as well. The definition makes clear that dress, besides a protective function, also has a social function (Eicher \& Roach-Higgins 1992/1993, 12).

In this article we focus on this second function: dress 'as a means of communication' (Roach-Higgins \& Eicher 1992, 1). Lynn Hume suggests that dress is a communicator of identity, individuality, group allegiance, beliefs, and the social order, for example (Hume 2013, 2). Dress is 'one form of non-verbal communication, full of symbolic meanings through which individuals locate themselves within their society, giving them personal and social identity' (Hume 2013, 3 referring to Goffman ${ }^{4}$ ). As non-verbal

4 Goffman 1973; the book by her to which she refers is unclear. 
communication, dress anticipates verbal communication (Barnes \& Eicher 1992/1993, 1). Dress also provides 'aesthetic pleasure' in either 'creating personal display' or in the appreciation of others (Roach \& Eicher 1979, 7).

In relation to religious dress Hume notes that dress is 'a visible signifier of difference' (Hume 2013, 2). She maintains that the message communicated is that the wearer chooses to follow a certain set of ideological or religious principles and practices (Hume 2013, 2). In this way dress distinguishes religious communities from each other, and within a group dress marks differences, for example, hierarchies, power structures, gender distinctions, and roles (Hume 2013, 2). The marking of different roles also evokes the wish for behaviour towards the role-taker. 'Knowledge of the person's role is necessary in order that one behaves appropriately toward them' (Barnard 1996/2002, 63). Dress symbolically ties the community together within a group (Roach \& Eicher 1979, 18). Barnes and Eicher explain that dress 'serves as a sign that the individual belongs to a certain group, but simultaneously differentiates the same individual from all others: it includes and excludes' (Barnes and Eicher 1992,1). Group identity can be forged by common vesture like uniforms defining 'a particular role or function played or authority held' (Holeton in Bradshaw 2002, 464). Holeton uses the term 'depersonalise' to explain that vesture is often used by institutions to depersonalise the wearer to emphasise the primacy of the institutional role over the personality:

In most western societies this use of vesture can still be seen in the courts, the universities and the churches. [...] [I]n the church, the vested individual acts in the name of the church or community and not on their own authority (Holeton 2002, 464).

Where dress during musical performances (concerts) is concerned, the literature suggests that the performer's dress influences the listener's musical experience (Griffiths 2010, 159-77). ' [...] [I]t is only through activity that music comes into being and therefore the visual code, which functions through the performer's body, is vital in transforming music into an embodied experience for an audience' (Griffiths 2011, 32 referring to Small 1998, 54). Not only hearing the music, but also seeing the performers in terms of dress and gesture, are important for the audience. The uniform mode of dress at concert performances sets the performers apart from the audience and 'diminishes the individuality of those who wear it, subordinating individuals to the collective identity' (Small 1998, 65). Wapnick, Mazza and Darrow 
have examined the effects of physical attractiveness, stage behaviour, and appropriateness of dress on evaluations of performance quality. Their conclusion is that non-musical attributes affect ratings of musical performances (Wapnick, Mazza \& Darrow 2000, 323). Pianists rated by observers-listeners as generically more attractive and more appropriately dressed achieved higher ratings of performance quality from observers-listeners (Wapnick, Mazza \& Darrow 2000, 323-36).

To obtain a more profound understanding of the production of the meaning of dress, we use Malcolm Barnard's concept, who, in line with the semiology of Ferdinand de Saussure (1857-1913), developed different types of meaning as an analytical tool (Barnard 1996/2002). This is useful in our research because of its multi-layered research field. Numerous interpretations of dress are possible: there are 'numerous interpretations by numerous cultural producers', which can differ from the originally intended meaning of a garment (Barnard 1996/2002, 33). The meaning of dress can differ from person to person, and the question arises if institutions can establish the meaning of dress.

Dress can be considered a 'sign', which is made up of the 'signifier' (the physical part) and the 'signified' ('the mental concept to which that signifier refers', Barnard 1996/2002, 81). Signifier and signified can be connected by a 'code', a set of shared rules (Barnard 1996/2002, 82). Barnard states: '[...] [I]f the code is unknown, then there is likely to be uncertainty as to what a particular signifier is signifying' (Barnard 1996/2002, 82). We use Barnard's concept of two different types of meaning as an analytical tool: a denotational meaning, i.e. the dictionary definition of the garment, and a connotational meaning, which may be described as what the garment makes a person think or feel, or as the associations that the garment evokes for someone (Barnard 1996/2002, 85). The connotational meaning depends on a person's social and cultural situation. Dress will have different connotations for different people. However, people from roughly the same cultural group will come up with almost identical connotations. If someone wants to identify himself with another person or represent an entire group, sometimes one garment is enough to evoke the connotation: for example, a child wearing a helmet 'is' a soldier. The helmet creates the connotation of the army and it does not matter precisely which rank the soldier has.

We use the concepts of denotation and connotation in the analysis of our fieldwork by describing denotationally what performers wear and by adding which meanings the performers connotationally attribute to dress. 


\section{Research method}

The meaning-making processes which concern us are best served by a bottom-up ethnographic approach, an approach which starts in the field with participant observation and analysis of interviews with key-informants: singers, organists, conductors, ministers, and visitors involved in the evensongs. In our research we observed what dress performers (singers, conductors, lectors, ministers or priests, and vergers, if present) wear at choral evensongs, and in our interviews we attempted to discover the meanings and functions participants attributed to dress at choral evensong. Participant observation has provided us with background information and a deeper understanding of the context, as well as access to interviewees.

Between 2008 and 2009 a pilot study was conducted at the monthly choral evensong of the Schola Davidica in the Janskerk in Utrecht, during which the first eight interviews were conducted. The research was continued as PhD research from May 2013. Between 2013 and 2015 participant observation was continued in twenty places ${ }^{5}$ with thirty choirs ${ }^{6}$ singing evensong in the Netherlands outside the context of the Anglican Church.

In the first phase of the empirical research we investigated where choral evensongs were held in the Netherlands. We made a general overview, a 'mapping of the field'. The second phase involved participant observation at various choral evensongs in the Netherlands. Our research conformed with the 'codes of conduct' formulated by the VSNU (the Association of Universities in the Netherlands). ${ }^{7}$ More specifically, the rules of the Code of Use of Personal Data in Research were followed. ${ }^{8}$ Research data were stored and will be kept for ten years at the Protestant Theological University in Amsterdam. Names of interviewees and interview places were anonymised.

More than twenty-five interviews with key informants (eight with singers, six with organists, six with conductors, four with ministers, and six with

5 E.g. Nieuwe Kerk Groningen, Martinikerk Groningen, Bovenkerk Kampen, Laurenskerk Rotterdam, Hooglandse Kerk Leiden, Domkerk Utrecht, Janskerk Utrecht, Nicolaikerk Utrecht, Oude Kerk Amsterdam, Nicolaaskerk Amsterdam, Pauluskerk Breukelen, Hervormde Kerk Hoornaar, Martinuskerk Zwaag, Grote Kerk Emmen, Oude Kerk Zeist, and Oude Kerk Zoetermeer.

6 E.g. Schola Davidica Utrecht, Kampen Boys Choir, Roden Boys Choir, Sweelinck Cantorij Amsterdam, Domcantorij Utrecht, Choral Voices Groningen, Anthem Zwolle, Kamerkoor Concertino, Martinuscantorij Zwaag, Magnificat Emmen, Leidse Cantorij, Culemborg Chapel Choir, Woerden Vocaal Ensemble, Projectcantorij Zoetermeer, Vespercantorij Utrecht, Marcantus Houten, Kerkkoor Hoornaar, Cappella Vesperale Eindhoven, Chorale by the Cappella Nicolai Amsterdam, Northern Voices, and Ichthus Cantorij Harlingen.

7 See <www.vsnu.nl>, accessed April 17, 2017.

8 See <www.vsnu.nl>, accessed April 17, 2017. 
visitors) were held. Respondents were usually collected via the secretary of the evensong choirs. We contacted the choir secretaries, asked in writing for permission for participant observation, and if it was possible to interview him or her in the week after the choral evensong. He or she also gave us the contact details of the director of music or the organist, and in some cases the minister. We conducted interviews, sometimes immediately after the choral evensong and sometimes in the week following it, with the leading persons (for example, the director of music, organist, or sometimes a minister). Usually, the interviews were conducted individually, but in some cases a group interview with the director of music and organist was conducted. We asked them for the contact details of singers and regular visitors to the evensong. After the interviews with the leading persons we conducted interviews with singers and visitors. Interviews were transcribed and data analysis was undertaken.

The first stage of interview analysis involved the coding of transcripts. We attempted to stay as closely as possible to the texts of the interviews, extracting the words participants used (in vivo coding) to describe the meanings they attributed to dress at choral evensong (Saldaňa 2009, 70-7). We compiled a lengthy list of all the keywords used, for example: 'England as a model', 'copy behaviour', 'own accentuation', 'self-created', 'staying in one line with the English choirs', 'showing your unicity', 'become quiet', 'uniformity', 'become part of the group', 'too ecclesiastical', 'metamorphose', 'giving a transcendental feeling', and 'touching the soul'. In the second phase of the analysis we looked for the most frequent keywords or themes (focused coding) (Saldaňa 2009, 151). We ordered the codes in three main categories: 'England as a model', 'identity', and 'metamorphosis and transcendence'. The category 'England as a model' involved remarks from interviewees about the popularity of the English tradition. The second category, 'identity', consisted of four subcategories: 'unicity of the choir', 'uniformity', 'group identity', and 'gender'.

\section{Empirical data}

We now present the data of our research on the dress of the choristers and ministers at choral evensong in the Netherlands. First, we describe the dress worn; we then elaborate on the meanings and functions attributed to it. 


\section{Dress at choral evensong in the Netherlands}

In all contexts (concert, worship, and concert and worship together) traditional Anglican dress is worn by the choristers. We observe an appropriation process ranging from exact copying of Anglican vesture to an à la carte approach to vesture. If clergy are present - usually one man or one woman - this copying behaviour is not followed.

We investigated the dress of thirty choirs singing choral evensongs: twenty-one wear choral robes at evensong, one choir wears black academic gowns, nine choirs wear black 'concert dress', and no choir wears casual clothing. In most instances (fifteen) choristers wear scarlet cassocks. In England scarlet may only be worn by royal permission, for example, at Westminster Abbey and some Cambridge college chapels. Dutch choirs copying English choir vesture seem to prefer scarlet.

Some choirs copy the scarlet cassocks and cotta of King's College Cambridge and the choir of Westminster Abbey in London exactly (with ruff collars for the boys). This is the case in seven of the thirty investigated choirs. Two choirs copy the black cassock with cotta as worn by the choir of St Paul's Cathedral.

We observe that there are exact similarities in the appropriation of Anglican choral dress, and also differences, for example, in the use of the cotta. In our research nine of the twenty-one robed choirs copy the cotta. The other choirs do not, for practical or aesthetic reasons or because, as interviewees explain, the cotta has too much of a Roman Catholic connotation for them (in the Roman Catholic tradition altar boys and acolytes sometimes wear cassock and the surplice-like cotta). Some choirs have decided for aesthetic reasons that only male singers may wear a cotta. In this case the cotta functions as a gender-marker. In the next section we elaborate on this.

In England choristers rehearse in cassocks and pull on their cottas just before the service starts. Cottas are only worn during worship; during concerts choirs wear cassocks without cottas. In the Netherlands during a concert choirs sometimes also wear a cotta. Although he does not agree with the practice, a conductor explained that one of his Dutch boys' choirs (in a Reformed context) also sang in cottas during concerts, because the red cassock reminded people too much of the Labour Party (interview with director of music, April 12, 2011).

Dutch choirs copy the wearing of badges and ribbons. In the Netherlands not only boys' choirs wear badges and ribbons, but also adults in mixed choirs (interview with director of music, April 12, 2011). At some choral evensongs we noticed a hood, worn by a choir conductor, for example. In 
England the hood points to an academic degree; in the Netherlands there is no relationship between the wearing of a hood and a degree from a Dutch university.

In nine places choirs wear (black) concert dress. Singers explained that they decided to wear uniform black dress because they were not singing at Sunday morning services. One choir decided to wear English black academic gowns with a blue accent.

If we now turn to the dress of ministers and readers at choral evensong in the Netherlands, the data show that the dress of the ministers is not appropriated from England. In nearly every case, with the exception of Old Catholic choral evensongs, there is a contrast between the dress of the choir and the dress of the minister. At nine choral evensongs there was no minister at all. Readers, selected for their correct English pronunciation, wear black clothes or, if they are a choir member, choristers' dress. At fifteen choral evensongs (mainly in a Reformed context) the minister wears his (or occasionally her) own 'Sunday morning vestments': a (black) Geneva gown (seven ministers), a Geneva gown with stole (two ministers), or an alb with stole (six ministers). Two ministers decided not to wear their Sunday morning vestments but a black suit. In two situations the minister was asked not to wear vestments, but casual clothes. One of the choir boards decided the choristers could wear choir dress, but ministers at choral evensong should not, to avoid the atmosphere becoming 'too ecclesiastical':

Since there are also visitors in the evensongs who do not regularly attend services, and since we would like to keep the threshold as low as possible, we prefer ministers to show in their attire that they are 'close' to ordinary people. Wearing a gown can create a distance for people who are not familiar with the church. (A member of the choir board read this part of a choir document from August 2013 during an interview, January 17, 2015).

\section{Meanings and functions attributed to dress}

In analysing the interviews, we identified three categories of meanings and functions participants attribute to dress at Anglican evensong. We present them below, adding some quotations to elucidate our research and, we hope, make it convincing.

The first category we identify is the reference to England as a model. Choral evensong choirs in the Netherlands wear choir dress because English cathedral choirs wear choir dress. A singer called this 'copy behaviour': 
Why do you wear choir dress?

It is of course in the first place copy behaviour. It's because you see the vestments in England. You see the vestments and think: 'Yes, that's the tradition there.' (Interviewed singer, April 26, 2011).

A choral conductor in the Netherlands explained why his boys' choir wears 'Anglican' liturgical dress:

And, of course also, because it comes from England. If you do something from England, you have to do everything from England. Not half-heartedly, but all the way! And this is then part of it. So, that is the function of the cassock in our situation. (Interview with conductor, April 12, 2011).

A singer explained in an interview that copying Anglican dress can be compared with copying the football shirts of your favourite football club, for example, the top Dutch football clubs Ajax or Feyenoord. For him, wearing Anglican dress marks his identification with the world's best singers (interviewed singer, November 17, 2013).

Dutch choirs copying English choir dress seem to prefer scarlet. One interviewee ascribed the preference for scarlet cassocks to the CDs of the choir of King's College Cambridge, which are popular in the Netherlands (interviewed singer, November 17, 2013). There are pictures of the choir in 'Queen's red' on the CDs' covers. Wearing this colour connotes an identification with some of the best Anglican choirs in the world.

The second category is the marking of identity. In the Netherlands evensong choirs copy dress or elements of dress from the English tradition, but add some elements to mark their own identity and unicity. On one hand the choirs want to share the English tradition; on the other the choirs want to distinguish themselves from England and, within the Netherlands, from other choirs. We will give some examples of this. One choir wears red choral robes (skirt with cape) with a red self-created shawl. The then organist said of these capes and shawls:

Our gowns look something like a winter cape: the winter cape which conductor Lisette Bernt wore on weekdays was really the example. Richard Seale, at that time choir master of Salisbury Cathedral, asked us if the Dutch climate had influenced our sacred dress (Oost 2008, 18 ${ }^{9}$ ).

The chairwoman explained that the choir decided to wear choir dress after ten years of discussion. They bought it because the choir needed robes for

9 Translation ours. 
their trips to England. In earlier periods the choir had borrowed choir dress from another choir, because there was resistance in the choir to wearing it. Half the choir found wearing it 'too ecclesiastical'. After ten years of discussion they decided to buy choir dress because of its connection with England, but with their own accentuation. The chairwoman explained that they decided that the dress also marked the unicity of the choir: 'And we wanted to express our unicity. Then a friend of one of the choral singers, she is a designer, designed this especially for us [...]' (interviewed singer, December 3, 2008). In this self-created new form of dress we observe that England is a model and at the same time there is a break with the tradition of the Anglican Church.

Another example is the wearing of a scapular instead of a cotta. As already mentioned, some choirs do not wear a cotta because for some Protestant choirs the cotta is 'too Roman Catholic'. A conductor explained why they decided to wear a scapular instead of a cotta:

Yes, a scapular [...]. When you wear a choral robe in a Reformed church and you also pull on a cotta, then it becomes very... Roman Catholic. Of course, it is Anglican. But that cotta was at the time at any rate a step too far. You associate it too much with Roman Catholic. And a scapular was a nice alternative [...]. In England you would have to have a cotta. Because in England they would think: what is that supposed to be? (Interview with conductor, September 24, 2014).

Besides the marking of unicity, there are aspects of uniformity and group identity. Surprisingly, all the investigated choirs wore uniform dress; in no case did the singers wear casual dress. This is interesting because it contrasts with many Dutch Protestant 'cantorij-praktijken' (regular church choirs at Sunday morning worship, who wear casual clothes so as not to distinguish themselves from the congregation). Interviewees explain that it is important that there is equality and uniformity in clothing. The uniformity also marks the group identity, as one interviewee explained (interviewed singer, March $12,2015)$. When wearing choir dress, you clearly stand out to everybody as a member of the choir.

In some choirs the cotta functions as a gender-marker. For example, male singers wear a cotta and female singers wear a small white collar. In another choir we observe gender playing a role in the choice of dress. The female singers wear a red cassock with cotta, while the male singers wear an alb with a red chasuble. In England the chasuble is only worn by priests, 
e.g. the red one is worn at Pentecost. Here, the dress code of the Anglican Church has been abandoned and vesture has adopted a new meaning.

In an interview a singer explained that her choir sings four times a year at the morning service in the Liberated Reformed (gereformeerde kerken-vrijgemaakt) congregation, since many of the choir's singers are members of this church. She explained that at the Sunday morning and Good Friday services the choir does not wear choral robes. They only wear them when they sing English choral music. 'When we sing on Sunday morning in a Reformed Liberated church, we do not pull on the choral vestments, because then it is...., yes, say..., liturgy (interviewed singer March 12, 2015). It seems that choir dress is not connected with liturgy, but a musical style.

The third category of meaning-making refers to 'metamorphosis and transcendence'. A conductor explained that the function of choir dress in his boys' choir was a 'metamorphosis':

Yes, the choir vestments, why we do that? Well, the boys undergo a metamorphosis [...]. When the boys pull on the cassock, then ... Beforehand, you see them jumping up and down the choir stalls and chatting with each other, and then they pull on the cassock... and that very moment, suddenly, they are quiet. Yes. Something changes, without us knowing exactly what it is. How and what ... (interview with director of music, April 12, 2011).

A singer explained that wearing choir dress lifts you out of the everyday: 'This garment has a special effect: it gives unity to the choir members, you feel lifted up to a higher level above the daily routine' (interview with staff member and singer, January 16, 2015). The singers connected this metamorphosis with transcendence; they explained that wearing choir dress at choral evensong lifted the singer to another, higher, atmosphere.

\section{Are people going to sing in a different way?}

Singer: Not singing in a different way, but it feels different. You are immediately lifted from the secular to a higher plane. You pull on the gown and then... you are not someone else, that is not the right word, but it feels different. (Interviewed singer, December 3, 2008)

One choir borrowed monastic habits from a monastery. One of the interviewees says that wearing the habits gives 'a more spiritual feeling' (interviewed singer, January 1, 2015).

We interpret this experience of 'the higher' and 'the spiritual' as a transcendental experience. An organist said wearing choir dress at choral 
evensong 'touches his soul' and connected it with the desire to experience something beyond everyday life:

Something happens when you pull on that thing. This is quite strange. When I walk in the procession, [...] I feel different, something happens with my soul. [...] As people we cannot live without the added value of praise in our lives. And we believe, in ourselves, in our lives, in the added value of our lives. And you have to show this in some way or other. [...] Showing it is also how you dress, funnily enough (interviewed organist, November 27, 2008).

\section{Discussion and conclusions}

In this final section we reflect on our fieldwork and relate it to our theoretical framework. We investigated which kind of dress is worn at choral evensong in the Netherlands and the meanings and functions attributed to it. We shared Meyer's material approach to religiosity: religion becomes concrete in the practices of people and their use of things (Meyer 2012, 7). We understand the practice of wearing Anglican-style dress at choral evensong as an expression of religiosity referring to unarticulated transcendental experiences. The sensational form of choral evensong generates meanings and experiences.

The data show that Dutch evensong choirs copy Anglican cathedral or college choristers' dress, sometimes very precisely, sometimes more loosely. Wearing choir dress affords a contrast with most Protestant (Reformed) services and with concert practices in general. We also observed that the dress of the clergy is not borrowed from England. In some cases there is no minister at the evensongs, and if there is, he or she may be asked not to wear any vestments, because, in the words of the interviewees, this is 'too ecclesiastical'. In summary, the results suggest that we can speak of a 'ceremonialisation' or 'cathedralisation' of choristers' dress, especially in contrast with what is usual at Protestant Sunday morning worship. It seems that tradition (in this case wearing specific dress) is freely used as a source: it is a game, and original meanings and functions are no longer valuable. If ministers are present, we observe that they are asked to dress casually to avoid appearing too ecclesiastical. What underlies the idea that singers wearing choir dress is not 'ecclesiastical', whereas if the minister wears 
vestments it is 'too ecclesiastical' $?^{10}$ The analytical tool of denotational and connotational meaning helps to clarify this confusing complexity. Singers start to wear Anglican choir dress because, as they explain in the interviews, it connotes the high musical and ritual quality of Anglican choral evensong choirs. In contrast, the dress of the Reformed minister connotes Dutch Reformed services, with their focus on the spoken word, the minister's dominant role, and little or no attention paid to liturgical choral music and the use of symbols or ritual. Most of the choirs singing choral evensong want to mark a contrast with Reformed practice in the Netherlands.

An analysis of our fieldwork reveals three categories. The first, 'England as a model', underlines that dress at choral evensong in the Netherlands communicates a connection with the high musical-ritual quality of Anglican choirs. Copying the scarlet of the best choirs' dress marks a longing for the highest musical quality. When they wear such dress, choirs become part of what the ethnomusicologist John Blacking has called a 'sound group': 'a group of people who share a common musical language, together with common ideas about music and its uses' (Blacking 1995, 232). However, there are also contrasts with Anglican practice. Dutch choirs create their own shapes and colour combinations to mark their unicity. In these personal transformations of the Anglican style choirs mark their individuality and unicity. In our fieldwork we observe that signifier and signified are no longer connected by shared established codes. Choirs do not follow the authorised codes, but create new meanings by using a 'deliberately different appropriation' (Barnard 1996/2002, 76). However, the authorised code of Anglican cathedrals is not appropriated. For choir members choir dress brings a connotation of Anglican cathedral music. We can perhaps speak of a 'de-institutialisation' (Van der Tuin 2008, 11), in which people turn away from the (institutional) church and deal freely with its traditions (Van der Tuin 2011, 63). Dress is appropriated in different ways and new meanings are generated (Frijhoff 1997, 108). The contrast with the Anglican tradition is also noticeable, for example, in the new meanings ascribed to the cotta, which is worn for aesthetic or quasi-political reasons, or as a gender-marker. According to Van der Tuin 'the vocabulary - words, images, symbols, music - in which these meanings are expressed sometimes contains traditional language: which, used in new contexts, should be interpreted anew $[\ldots]^{\prime}$

10 We supposed that the difference in the interpretation of 'ministry' between the Anglican Church and the Reformed Churches in the Netherlands may have played a part, but surprisingly, this did not emerge from the fieldwork. 
(Van der Tuin 2008, 2111). The dress code of the Anglican Church is transformed into a new code which can be seen as a form of bricolage indicating an 'unconventional combination of conventional topoi in a completely transformed context' (Barnard 2006, 75; see also Van der Sijde 1998, 56v). Bricolage is characteristic of post-modernity. 'Everybody picks from the separate systems what pleases him or her and makes his own religious system [...] (Van der Tuin 2008, 15).

The remarkable combination of ecclesiastical dress worn by the choirs and the explicitly non-ecclesiastical dress of the ministers suggests what the French philosopher Marcel Gauchet called 'the religious after the religion' (Gauchet 1985, 200). There seems to be a deliberate decoupling of the institution and the experience of religiosity (Van der Tuin 2008, 15).

Once disposed of its institutional ballast and individualized to a personal experience, religion returns in new forms. People are longing for meaningfulness, depth and interpretation. They are looking for something transcending (Van der Tuin 2008, 15).

Anthropologist Anton van Harskamp speaks of a 'new religious longing' and 'new religiosity' (Van Harskamp 2000, 48). In line with this Van de Donk and Jonkers mention that appearances of 'new religion' are not characterised by 'pressure from above' but rather offer 'non-compulsory choice options' (Van de Donk and Jonkers 2006, 14). The references to 'metamorphosis and transcendence' show that participants experience wearing Anglicanlike dress at choral evensong as a transcendental connection, although this experience remains unarticulated.

Taken together, the fieldwork data reveal that dress at choral evensong in the Netherlands points to changing religiosity at two different levels. First, we observe a transformation of the way religion is expressed or ritualised in the context of Reformed Protestant churches in the Netherlands. The popularity of evensong suggests a longing for other forms of worship, with a focus on ceremony, ritualised behaviour, and Anglican-like vesture for the choristers. Second, we observe a mix of concert practices and Anglicanlike rituals which our interviewees refer to as a new form of religiosity. In both practices the traditional dress of the Anglican Church is used, whether copied exactly or adapted.

11 Cited in Hoondert 2015. 
A new phenomenon arises: choirs wear Anglican-like dress decoupled from the Anglican Church as they long for transcendental experiences, which they find in the musical-ritual form and high musical quality of choral evensong.

HANNA RIJKEN, PhD, theologian and professional musician, defended in December 2017 her PhD thesis entitled "My Soul Doth Magnify'. The Appropriation of the Anglican Choral Evensong' in December 2017 at the Protestant Theological University in Amsterdam, the Netherlands. E-mail: hannarijken@hotmail.com

MARTIN J.M. HOONDERT is Associate Professor of Music, Religion \& Ritual at the Tilburg School of Humanities, the Netherlands. E-mail: m.j.m.hoondert@ tilburguniversity.edu.

MARCEL BARNARD is professor of Practical Theology/ Liturgical Studies at the Protestant Theological University, Amsterdam, and professor of Liturgical Studies at Vrije Universiteit Amsterdam, and Professor Extraordinary of Practical Theology at the University of Stellenbosch (South Africa).

References

Arthur, L. (ed.)

1999 Religion, Dress and the Body. Oxford/New York: Berg.

Barnard, $M$.

2002 (1996) Fashion as Communication (second edition). London/New York: Routledge.

2006 Liturgie voorbij de Liturgische Beweging: Over Evangelical Worship, Thomasvieringen, kerkdiensten in migrantenkerken en ritualiteit op het internet. Zoetermeer: Meinema.

Barnard, M., Cilliers, J., \& Wepener, C.

2014 Worship in the Network Culture: Liturgical/Ritual Studies - Field and Methods, Concepts and Metaphors. Leuven: Peeters.

Barnes, R. \& Eicher, J. B. (eds)

1992/1993 Dress and Gender: Making and Meaning in Cultural Contexts. Providence/Oxford: Berg. 
Bernts, T. \& Berghuijs, J.

2016 God in Nederland 1966-2015. Utrecht: Uitgeverij Ten Have.

Borgman, E.

2006/2010 Metamorfosen. Over religie en moderne cultuur. Kampen: Uitgeverij Klement.

Blacking, J.

1995 Music, Culture, and Experience: Selected papers. (R. Byron, ed). Chicago.

de Certeau, $M$.

1984 The Practice of Everyday Life. Berkeley/Los Angeles: University of California Press.

Chartier, R.

1988 Cultural History between Practices and Representations. Ithaca, N.Y.: Cornell University Press.

Dant, T.

1999 Material Culture in the Social World. Buckingham: Open University Press.

Donk, van de, W. (et al.)

2006 Geloven in het publieke domein: Verkenningen van een dubbele transformatie $(=$ WRR verkenningen 13). Amsterdam: Amsterdam University Press.

Donk, van de, W. \& P. Jonkers

2006 Geloven in het publieke domein: Een introductie van deze verkenning. - Geloven in het publieke domein: Verkenningen van een dubbele transformatie (=WRR verkenningen 13), 13-24. Amsterdam: Publisher.

\section{Eicher, J.B. \& M.E. Roach Higgins}

1992/1993 Definition and Classification of Dress: Implications for Analysis of Gender Roles. - Barnes, Ruth \& Eicher, Joanne B. (eds), Dress and Gender: Making and Meaning in Cultural Contexts, 8-28. Providence/ Oxford: Berg.

Evans, $M$.

2003 The Sacred: Differentiating, Clarifying and Extending Concepts Review of Religious Research 45 (1), 32-47.

Frijhoff, W.

1997 Toe-eigening: van bezitsdrang naar betekenisgeving - Trajecta 6, 99-118.

1998 Heiligen, idolen, iconen. Nijmegen: SUN.

Gauchet, $M$.

1985 Le désenchantement du monde. Paris: Gallimard. 


\section{Gibaut, J.}

2006 The Daily Office. - Charles Hefling \& Cynthia Shattuck, The Oxford Guide to the Book of Common Prayer: A Worldwide Survey, 451-60. Oxford: Oxford University Press.

\section{Griffiths, N. K.}

2010 'Posh music should equal posh dress': an investigation into the concert dress and physical appearance of female soloists. - Psychology of Music 38 (2), 159-177.

2011 The fabric of performance: values and social practices of classical music expressed through concert dress choice. - Music Performance Research 4, 30-48.

Hall, S.

1997 Representation: Cultural Representations and Signifying Practices. London: Sage Publications.

Harskamp, van, A.

2000 Het nieuw-religieuze verlangen. Kampen: Kok.

Hart, de, J.

2011/2013 Zwevende gelovigen: oude religie en nieuwe spiritualiteit. Amsterdam: Bert Bakker.

Holeton, D. R.

2002 Vestments - Bradshaw, P. (eds), The New Westminster Dictionary of Liturgy E Worship, 464-71. Louisville: Westminster John Knox Press.

Hoondert, M. J. M.

2015 Musical Religiosity. - Temenos. Nordic Journal of Comparative Religion 51 (1) 123-36.

\section{Jespers, F.}

2009 Nieuwe religiositeit in Nederland. Gevalstudies en beschouwingen over alternatieve religieuze activiteiten. Budel: Damon.

\section{Meyer, B.}

2012 Mediation and the Genesis of Presence: Towards a Material Approach to Religion. Utrecht: Universiteit Utrecht.

\section{Norris, P. \& R. Inglehart}

2004 Sacred and Secular: Religion and Politics Worldwide. Cambridge: Cambridge University Press.

Oost, G.

2008 Alternatief geloven. Een bundel opstellen over geloven in muziek. Zoetermeer: Boekencentrum. 


\section{Roach-Higgins, M.E. \& J.B. Eicher}

1992 Dress and Identity. - Clothing and Textiles Research Journal 10, 1-8.

\section{Roach, M.F. \& J.B. Eicher}

1979 The Language of Personal Adornment: Cordwell, J.M., and Schwarz, R.A. (eds): The Fabrics of Culture, 7-23. The Hague: Mouton.

\section{Ruffer, T.(eds)}

2009 The Voice for Life Chorister's Companion. Salisbury: RSCM Press.

Rijken, H. \& M.J.M. Hoondert \& M. Barnard

2013 My Soul Doth Magnify: The Appropriation of the Anglican Choral Evensong in the Dutch Context. Presentation of a Research Project. - Yearbook for Liturgical and Ritual Studies 29, 83-98.

Saldaňa, J.

2009 The Coding Manual for Qualitative Researchers. London: Sage Publications.

Sengers, E., (ed.),

2005 The Dutch and their Gods: Secularization and Transformation of Religion in the Netherlands since 1950. Hilversum: Verloren.

van der Sijde, $\mathbf{N}$.

1998 Het literaire experiment. Jacques Derrida en de literatuur. Amsterdam/ Meppel: Boom.

Small, C.

1998 Musicking: The Meanings of Performing and Listening. Middletown: Wesleyan University Press.

van der Tuin, L. W. J. M.

2008 God droeg zondagavond een blauwe trui. Tilburg: Fontys Hogescholen.

\section{van der Tuin, $\mathrm{L}$.}

2011 De nieuwe kleren van religie. - L. van der Tuin \& P. van Zilfhout (eds) De nieuwe kleren van religie. Teksten van de expermeeting en het college bij gelegenheid van het afscheid van Leo van der Tuin, 59-83. Tilburg: Fontys Hogescholen.

\section{Wapnick, J. \& J.K. Mazza \& A.A. Darrow}

2000 Effects of Performer Attractiveness, Stage Behavior, and Dress on Evaluation of Children's Piano Performances. - Journal for Research in Music Education 48 (4), 323-336.

Ward, $\mathbf{P}$.

2002 Liquid Church. Massachusetts: Hendrickson Publishers.

Wolfe, A.

2003 The Transformation of American Religion. How We Actually Live Our Faith. Chicago: University of Chicago Press. 